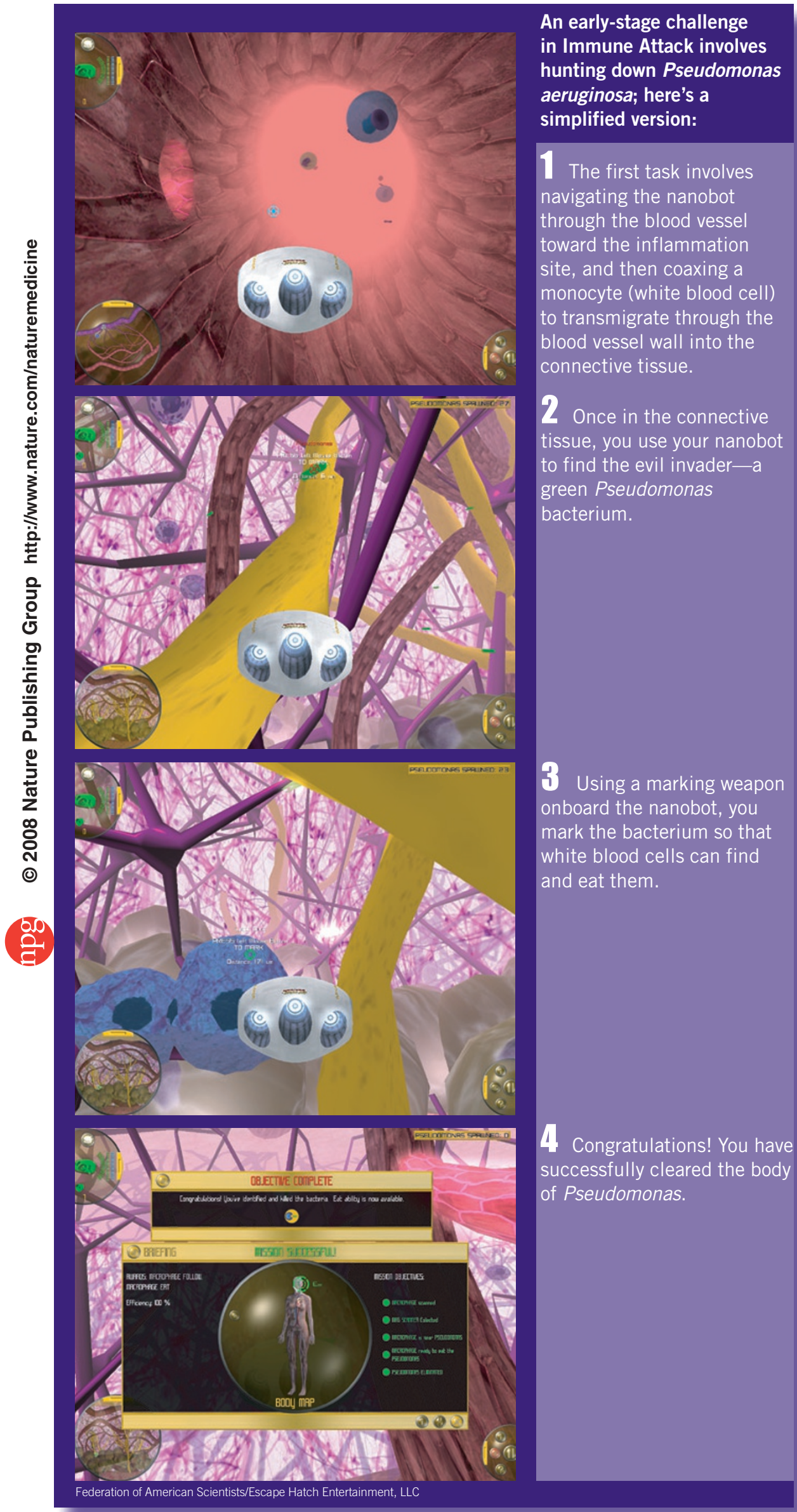

\section{The fight of your life}

At first, Immune Attack seems like any other video game that teenagers might gravitate toward: the quest requires navigating a nanobot through dark, dangerous tunnels to find and destroy evil opponents. It's all familiar, except that in Immune Attack, the tunnels you navigate are blood vessels, and the bad guys go by menacing Latin names such as Pseudomonas aeruginosa.

At the start of the game, players enter the body of a person who has a unique condition in which the immune system is "present, yet nonfunctional," with immune cells that have forgotten what to do.

The goal is to train different components of the human immune system to go after invading pathogens, including P. aeruginosa, a bacterium that can cause swimmer's ear. Players must select the right immune signaling molecules from their arsenal to fight off the infectious agents.

"Your body is basically at war" with foreign viruses and microbes, says Michelle Roper, who has led the development of the game at the Washington, DC-based Federation of American Scientists. "So that's the analogy we used. We joked that it could be dubbed 'the bloodiest game, ever."

Roper explains that the Immune Attack video game is designed to help students, particularly those learning high school-level biology, test and improve their knowledge of the human immune system.

Her team has so far conducted trials with different versions of the game with approximately 500 students aged $15-17$ years and plans to make the game available (on the Federation of American Scientists website at www.fas.org/immuneattack) in early March 2008.

The game will initially be free for students and educators to download, with a suggested nominal donation to help with further game development.

Even though Immune Attack does measure players' knowledge of biology, it looks nothing like a typical standardized test. Instead of ticking off answers on a sheet of paper, students maneuver the nanobot through body tissues that resemble the surfaces of strange planets.

"The body really does lend itself to these alien environments," says Garry Gaber, president of Escape Hatch Entertainment, the computer game development studio based in Austin, Texas, that helped create the game.

Roxanne Khamsi, New York 